\title{
Knowledge Management Practices in Steel Industries of India: A Comparative Analysis of Public and Private Steel Industries
}

\section{Srinibash Dash ${ }^{1}$, Sundhansu Sekhar Rath ${ }^{2}$}

${ }^{1}$ Assistant Professor, School of Management, Gangadhar Meher University, Sambalpur

${ }^{2}$ Former Vice Chancellor, Gangadhar Meher University

${ }^{2}$ Former Professor, P.G. Department of Economics, Sambalpur University, Sambalpur

Article History: Received: 10 November 2020; Revised: 12 January 2021; Accepted: 27 January 2021;

Published online: 05 April 2021

Abstract: The purpose of this paper is to study the knowledge management practices of steel industries in India. The Indian
economy is considered a mixed economy. Indian steel industry having the participation from both private and public sector
enterprises is one of the fastest-growing industries in terms of steel production and is also increasingly looking towards
export as driving the growth of the industry. Under this study both public and private steel industries are taken into
consideration. The study was based on secondary data. This research brings a research report on the impact of Knowledge
Management Practices (KMP) in the Indian steel industries. The analysis was made by taking the previous year's data
regarding various matters relating to KMP and its pros and cons in the performance of the Indian steel industries. The
comparison was done between these two i.e., both public and private steel companies of the country.
Keywords: Knowledge Management Practices (KMP), Public Steel Companies, Private Steel Companies.

\section{Introduction}

With the development of economies driven by industrialization toward the start of the 20th century, nations with sound steel enterprises profited by a first-mover advantage. India got free in the center of this century and hoped to get self-subordinate under its recently embraced model of this mixed economy. To accomplish this objective, the three significant fragments i.e., primary (raw-materials), secondary (assembling \& manufacturing) and tertiary (services) areas must be grown at the same time. As raw material and intermediate product, steel was the common link among all the above three segments. Now-a-days the usage of steel is high as compared to other kinds of products.

In this current world, the steel business contributes marginally over $2 \%$ to the GDP of the country. This percentage represents the direct contribution of the total usage. The indirect contribution of steel is larger than the direct contribution. The steel industry employs nearly half a million people directly and two million people indirectly in the country. According to World Steel Association (WTA), at least two jobs are created daily in the steel industries.

However, India is right now the world's second-biggest producer of unrefined/crude steel, with 110.92 MT created in 2018-19 (up from 103.13 MT in 2017-18). The nation has reinforced its domestic steel industry significantly in the course of the most recent decade. It turned into complex industries managing with different responsive/non-receptive components/elements. Enormous strength, low weight, toughness and flexibility easily make steel the most important crude material of the assembling area. Steel has contributed largely to India's financial development. This is evident from the similar development of India's GDP and steel production in the country, which additionally features the economy's reliance on steel.

Public utilization in terms of finished steel increases from 6.5 MT in 1968 to 98.71 MT in 2018, while GDP (at consistent cost, 2010) developed from USD 0.25 trillion out of 1968 to USD 2.7 trillion today.

Table 1.1. World Crude Steel Production: Top 10 Countries, 2019 (January-December, 2019

\begin{tabular}{|c|c|c|c|c|}
\hline Rank & Country & $\begin{array}{c}\text { Quantity } \\
\text { (in Million Tons) }\end{array}$ & \% Change over 2018 & \% Share in 2019 \\
\hline 1 & China & 996.30 & 8.3 & $\mathbf{5 3}$ \\
\hline 2 & India & 111.20 & 1.7 & 5.9 \\
\hline 3 & Japan & 99.30 & $(-) 4.8$ & 5.3 \\
\hline 4 & USA & 87.80 & 1.4 & 4.7 \\
\hline 5 & Russia & 71.60 & $(-) 0.6$ & 3.8 \\
\hline 6 & South Korea & 71.40 & $(-) 1.5$ & 3.8 \\
\hline 7 & Germany & 39.70 & $(-) 6.4$ & 2.1 \\
\hline 8 & Turkey & 33.70 & $(-) 9.7$ & 1.8 \\
\hline
\end{tabular}




\begin{tabular}{|c|c|c|c|c|}
\hline 9 & Brazil & 32.20 & (-) 9.0 & 1.7 \\
\hline 10 & Iran & 31.90 & 30.2 & 1.7 \\
\hline \multicolumn{2}{|c|}{ Top 10} & 1575.10 & 4.7 & 84.0 \\
\hline \multicolumn{2}{|c|}{ World } & 1874.23 & 3.3 & 100.0 \\
\hline
\end{tabular}

Table 1.1., shows that India is the second-largest crude steel production in the world. The production of the country for the year 2019-20 is 111.20 million tons which is the highest after China. After the implementation of HRD \& KMP practices, it seems that the employees are getting motivated themselves and using their best efforts and knowledge for the betterment of the organization. The percentage of productions are also gradually increasing i.e., from $1.7 \%$ to $5.9 \%$ for the 2018 to 2019 F.Y. Hence, it is showing a positive figure throughout the year. In India, the performance of KM practices has a significant impact on the production of crude steel as it energies, motivates the employees in the organization so as to give his/her best for the development of the organization in a smooth and efficient manner.

Table 1.2. Total Capacity Utilization of Steel Industries in India

\begin{tabular}{|c|c|c|c|}
\hline Year & $\begin{array}{c}\text { Capacity } \\
\text { (In Million Tons) }\end{array}$ & $\begin{array}{c}\text { Production } \\
\text { (In Million Tons) }\end{array}$ & Capacity utilization (\%) \\
\hline $2014-15$ & 109.85 & 88.98 & 81 \\
\hline $2015-16$ & 121.97 & 89.79 & 74 \\
\hline $2016-17$ & 128.28 & 97.94 & 76 \\
\hline $2017-18$ & 137.97 & 103.13 & 75 \\
\hline $2018-19$ & 142.24 & 110.92 & 77 \\
\hline $2019-20 *$ & 142.24 & 82.192 & 78 \\
\hline \multicolumn{2}{|l}{ Source: Ministry of Steel, GOI, Annual Report 2019-20, *Provisional; for April-December, 2019 } \\
\hline
\end{tabular}

Table 1.2 states that the production of the steel industries of India is in an upward direction as it constantly is in incresing stage i.e., from the year 2014-15 to 2019-20 and the production is increasing 109.85 and 142.24 respectively. The utilization capacity of the steel industries is also constant throughout the year. This shows a positive figure for the country in terms of capacity and its utilization process.

However, the biggest challenge of the organization is setting up a knowledge management practice which states knowledge is decentralized. The majority of knowledge management processes shouldn't be centralized. For example, it's not a good idea to centralize knowledge identification, creation, validation, assessment and use. The successful knowledge management practice recognizes the distributed nature of knowledge. They focus on those shared knowledge management services that can be centralized. From the above Table 4.3, it has come to the notice that, the steel industries are exporting more as compared to its import i.e., 6.519 is greater than 5.514 Million Tons in terms of quantity. The total capacity utilization is $77 \%$ in the respective financial year. This shows that steel industries are focusing on export rather than import in order to increase more revenue for the industry.

\section{Knowledge Management Practices in SAIL (Public Sector)}

Steel Authority of India Limited (SAIL) is an Indian state-possessed steel-making organization situated in New Delhi, India. It is a public undertaking, possessed and worked by the Government of India with a yearly turnover of INR 66,267 Crore (US\$9.32 Billion) for the financial year 2018-19. Consolidated on 24 January 1974, SAIL has 68,742 representatives (starting at 01-Jun-2020). With a yearly creation of 16.30 million metric tons, SAIL is the twentieth biggest steelmaker on the planet and the biggest in India. The Hot Metal creation limit of the organization will additionally increment and is relied upon to arrive at a degree of 50 million tons for each annum by 2025 .

SAIL works and owns 5 incorporated steel plants at Bhilai, Rourkela, Durgapur, Bokaro, and Burnpur (Asansol) and 3 unique steel plants at Salem, Durgapur, and Bhadravathi. It also owns a Ferro Alloy plant at Chandrapur. The organization is going through a massive development \& expansion and modernization program including upgrading and building new offices with an emphasis on the state of the art of green technology. As indicated by a recent survey, SAIL is one of India's quickest developing Public Sector Units. Furthermore, it has an R\&D community for Iron and Steel (RDCIS), the place for Engineering in Ranchi, Jharkhand. 
Hence, in today's scenario, the Knowledge Management Practices (KMP) is a very dynamic and innovative concept for boosting the financial growth of the organization. For this, the steel industries are adopting many HRD and KM practices so as to maintain the growth and prosperity of the organization. This KMP plays a vital role in achieving the strategic goals of the company. The Knowledge Management Practices of Steel Authority of India Limited (SAIL) are enumerated below:

1. SAIL using KMP by mapping and structuring the knowledge assets so as identify the specific goals and state the reasons for how and where to achieve.

2. The SAIL disseminates the knowledge among the employees for knowledge-sharing purposes.

3. It contextualizes and codified the knowledge by applying different knowledge management indexes.

4. SAIL industries give chance to each and every employee to discover new knowledge.

5. Implementation of knowledge sharing policy

6. Motivational programs are conducted for the development of KM process

7. Discrimination of knowledge management practices.

8. The performance level of SAIL's is increasing stage due to its smooth functioning of both Human Resource Development (HRD) and Knowledge Management Practices (KMP) in the organization.

\subsection{Impact of Knowledge Management for the performance level of SAIL}

Table 4.4, shows that SAIL's production is in an increasing stage starting from 2014-15 to 2019-20 F.Y The SAIL's have so many knowledge management practices for the development of the concern. After the implementation of KMP in the industries, the production growth and the percentage of performance growth have a positive correlation between them. The production of SAIL's hike from 88.98 MT to 110.92 MT. This gives a positive impact on KMP in the organization. The production and its growth continuously are in an upward direction. This means workers, employees and staff are efficient in their work, skilled personnel are appointed, motivated employees performing well. Finally, all HRD \& KMP in SAIL's has a good impact on the overall development of the concern.

Table 2.1. Impact of KMP on SAIL

\begin{tabular}{|c|c|c|c|}
\hline Year & Knowledge Management Practices & $\begin{array}{l}\text { Production Growth } \\
\text { (in Million Tons) }\end{array}$ & $\begin{array}{c}\text { Performance } \\
\text { Growth } \\
(\text { in } \%) \\
\end{array}$ \\
\hline $2014-15$ & \multirow{6}{*}{$\begin{array}{ll} & \text { Knowledge management culture } \\
> & \text { Skill development programmes } \\
> & \text { Knowledge measurement practices } \\
> & \text { Knowledge integration policy } \\
> & \text { Training \& development } \\
> & \text { Skill development initiatives }\end{array}$} & 88.98 & - \\
\hline $2015-16$ & & 89.79 & 0.91 \\
\hline $2016-17$ & & 97.94 & 9.07 \\
\hline $2017-18$ & & 103.13 & 5.30 \\
\hline $2018-19$ & & 110.92 & 7.55 \\
\hline $2019-20 *$ & & $82.19 *$ & $(25.90)$ \\
\hline
\end{tabular}

However, if we consider its reviews and ratings in terms of all activities i.e., skill development, job security, work satisfaction, etc. then out of 270 reviews and 5 ratings, the highest ratings i.e., 4.5 falls under job security. On the contrary, the second-highest rating goes to skill development initiatives ratings is 4.3 , which are generally coming under knowledge management practices.

Table 2.2. Total Expenditure on R\&D (Knowledge Management Practices) (Rs. in Crore)

\begin{tabular}{|c|c|c|c|c|c|}
\hline YEAR & \multirow{2}{*}{$\begin{array}{c}\text { SAIL's } \\
\text { Turnover }\end{array}$} & \multicolumn{4}{|c|}{ R \& D Expenditure by SAIL } \\
\cline { 3 - 6 } & Resource & Revenue & Total & \% of Turnover \\
\hline $2015-2016$ & 43294 & 50.78 & 226.22 & 277.00 & 0.64 \\
\hline $2016-2017$ & 49180 & 77.83 & 261.60 & 339.43 & 0.69 \\
\hline $2017-2018$ & 58297 & 20.79 & 314.71 & 335.50 & 0.58 \\
\hline $2018-2019$ & 66267 & 14.77 & 305.09 & 319.86 & 0.48 \\
\hline
\end{tabular}




\begin{tabular}{|l|c|c|c|c|}
\hline $\begin{array}{c}\text { 2019-2020* (Apr- } \\
\text { Dec) }\end{array}$ & 45001 & 4.84 & 155.10 & 0.36 \\
\hline
\end{tabular}

From the above Table 2.1.2, it states that the total expenditure of the steel industries in R\&D is considered as part of knowledge management practices. The turnover of the SAIL is in the increasing stage. The percentage of turnover is in zigzag conditions it means sometimes higher and sometimes lower. The resource of SAIL's is minimum in 2018-1 F.Y. This situation indicates that there is a positive correlation between resource and turnover of SAIL. After the implementation of KMP in steel industries, the turnover remains to stand in an upward direction.

\section{RSP Knowledge Management Practices}

Rourkela Steel Plant (RSP) which is set up in the Rourkela district of Odisha is considered the first incorporated steel plant in India. It was set up with West Germany cooperation with an introduced limit of 1 million tons during the 1960s. It is operated by Steel Authority of India Limited (SAIL). German metallurgical firms Mannesmann, Krupp, Demag, Siemens, and Austrian organization Voestalpine gave hardware and consultancy to the plant among others.

However, Rourkela Steel Plant (RSP) was the first steel plant in Asia to utilize the LD (Linz-Donawitz) cycle of steel-production. RSP has a related compost plant that produces nitrogenous manures utilizing smelling salts feedstock (from its coke stove plant). On 3 February 1959, at that point previous president Dr. Rajendra Prasad introduced RSP's first impact heater named 'Parvati' when the organization was known as Hindustan Steel Limited (HSL). Thusly, the RSP turned into a unit of the (SAIL).

However, the Knowledge Management Practices of Rourkela Steel Plant (RSP) are adopting KMP in respect of the following points:

1. RSP developing knowledge management culture for KMP practices.

2. RSP develops knowledge management tools for the promotion of skill, knowledge of the employees.

3. Knowledge compliance activities are made for KMP process implementation.

4. Integration of knowledge management practices are conducted for KM process.

5. RSP follows the knowledge measurement \& reporting process in knowledge management.

6. Continuous knowledge management improvement process.

The ratings and reviews of Rourkela steel Plant (RSP) have the highest ratings i.e., 3.7 ratings fall under skill development activity which is a part of KM practices. In terms of career growth, the rating is 3.0. This statement indicates that the companies are smoothly functioning the HRD and KM practices for the development of the concern.

\section{BOKARO Knowledge Management Practices}

The KM practices of Bokaro Steel Plant are the fourth integrated steel plant in the Public Sector Undertakings (PSU) was established in 1965 in collaboration with the Soviet Union. It was initially consolidated as a limited company on 29th January 1964, and was subsequently merged with SAIL, first as a subsidiary company and afterward as a unit, through the Public Sector Iron and Steel Companies (Restructuring and Miscellaneous Provisions) Act 1978. The construction \& development work began on the sixth of April 1968.

This BOKARO steel plant is termed as the first Swadeshi Steel Plant (SSP) in India. This plant is built with various indigenous contents that are mentioned in terms of the development of types of equipment, utilization of materials, and know-how in the organization. Its first Blast Furnace began on second October 1972 and in the first phase, 1.7 MT Ingot steel was manufactured. The commissioning of the third Blast Furnace was held on $26^{\text {th }}$ February 1978. All units of the 4 MT stage have just been charged and the modernization taken up in the nineties has additionally overhauled this to $4.5 \mathrm{MT}$ of fluid steel.

\subsection{Knowledge Management Practices of BOKARO Steel Plant}


The knowledge Management Practices of this plant is specific and widely used. This plant focuses on knowledge-sharing policies for achieving strategic goals. The plant also deals with training and development programs relating to knowledge discrimination and farmers' development. The important role of this plant is the participation of decision-making where every employee contributes his/her knowledge for the development of the concern. The KMP of this plant is as follows:

1. Mutual decision-making process

2. Knowledge sharing methods

3. Discrimination of Knowledge development programme

4. Socialization of KMP practices through employees, etc.

However, the ratings and reviews of Bokaro Steel Plant out of 36 employee reviews the highest rating falls on skill development activities i.e., 4.1. This statement indicates that the employees are getting too much benefit from this plant in terms of KM practices.

\section{BHILAI Knowledge Management Practices}

The Bhilai Steel Plant (BSP), situated in Bhilai, in the Indian province of Chhattisgarh, is India's first and fundamental maker of steel rails, as well as a large producer of wide steel plates and other steel items. The plant additionally delivers steel and markets different compound results from its coke ovens and coal chemical plant. It was set up with the assistance of the USSR in 1959.

Bhilai Steel Plant (BSP) is an eleven-time victor/winner of the Prime Minister's Trophy for best-incorporated steel plant in the country. The plant is the sole provider of the nation's longest rail tracks, which measure 260 meters $(850 \mathrm{ft})$. The 130 - meter rail, which would be the world's longest rail line in a solitary piece, was moved at URM, Bhilai Steel Plant (SAIL) on 29 November 2016. The plant likewise delivers items, for example, wire bars and dealer items. Bhilai Steel Plant has been the lead incorporated steel plant unit of the Public Sector steel organization, the Steel Authority of India Limited, and is its biggest and most beneficial creation office. It is the lead plant of SAIL, contributing the biggest level of benefit in terms of the higher percentage of profit.

\subsection{Knowledge Management Practices of BHILAI Steel plant}

The KM practices of BHILAI steel plants are also unique and desirable. This plant procures the ideas of the management thinkers/ intellectuals and employees of the concern for the development of the organizational structure. This plant primarily deals with the employee for sharing his/her best knowledge for the development of strategic decision-making process. However, this plant energizes the employees by motivational speech or programs for putting best efforts or knowledge for the welfare of the concern.

The ratings and reviews of this out of 36 reviews have the highest rating in work-life balance i.e., 4.3 out of 5 ratings. 4.1 ratings fall in pay \& benefits activities and so on. It means this plant providing the highest payment in terms of rewarding the employees for KM practices.

\section{Highlights of KMP in Public Steel Companies}

The KM practices in public steel companies are now a big and dynamic role for the concern. The KM practices are generally maintained by the companies by giving the chance of knowledge sharing to the concerned employees. The manpower positions of the public companies have also a great impact on KM practices. The highest manpower position indicates a higher intervention of knowledge in the management decision-making process. The companies are motivating the employees to put his/her best knowledge practices for the development of the concern and for this the companies are rewarding with various services to the departmental workers/employees. Hence, as we know that KMP \& HRD are the two sides of a success coin as it stimulates the whole organization for achieving the strategic goals faster and safe manner. The public companies are also using knowledge management tools for implementing, sharing the knowledge to achieve the specific goals faster.

Table 6.1. Financial Performance of Steel Industries in India, (Rs. in Crore)

\begin{tabular}{|l|c|c|}
\hline Parameter & $\mathbf{2 0 1 8 - 1 9}$ & $\mathbf{2 0 1 9 - 2 0} *$ \\
\hline Turnover & 2927.00 & 733.65 \\
\hline Operating Profit & $(267.96)$ & 94.51 \\
\hline Profit Before Tax & $(269.21)$ & 93.36 \\
\hline Profit After Tax & $\mathbf{( 3 2 4 . 4 7 )}$ & $\mathbf{6 0 . 7 4}$ \\
\hline
\end{tabular}


Source: Ministry of Steel, GOI, Annual Report 2019-20; *Provisional up to December 2019

From the above Table No. 6.1, the turnover of the steel industries in India remains in a good position in 201819 and 2019-20 F.Y. The financial performance of the steel industries is in increasing stage after adopting HRD \& KM practices. Hence, the manpower position plays a dominant role in enhancing the financial position of the business. The steel industries are generating a standard operating profit in the 2018-19 period i.e., 267.96 crores.

\section{Knowledge Management Practices (KMP) in Private Steel Companies}

The private Steel Industry is a booming industry everywhere in the world. The expanding interest for it was primarily generated by the improvement \& development of various projects that have been going on along the world, particularly the infrastructural works and real estate projects that have been on the blast around the nonindustrial nations. It has been seen that Private Steel Industry has filled colossally in the last one and a halfdecade with a solid monetary condition. The Annual Report 2010-11 by the Ministry of Steel, underpins the above truth as India has arisen as the fifth-biggest maker of steel in the world and is probably going to turn into the second-biggest maker of rough steel by 2015-16. Steel creation rose 4.5 percent to arrive at 50.59 MT in 2010-2011, as per the Ministry of Steel. The steel utilization more than the 2010-2011 period was accounted for 44.28 MT in India and expanded by $8 \%$ over the earlier year. The National Steel Policy 2005 had projected a yearly steel utilization development of 7 percent dependent on GDP development pace of 7-7.5 percent and creation of 110 MT of rough steel by 2019-2020. In any case, with the current pace of continuous Greenfield and Brownfield projects, the Ministry of Steel has projected that these development patterns are probably going to be surpassed and it is visualized that in the following five years request will develop at a higher yearly normal development pace of more than $10 \%$. However, the manpower position of the private steel industries continuously is in increasing stage due to the intervention of KM practices in the organization. The higher intervention of manpower leads to higher discrimination of knowledge in the organization. Hence, the positions of manpower also have a great impact on KMP \& HRD practices in the concern.

The Knowledge Management Practices (KMP) of these private steel companies is dynamic and widely acceptable. The KMP of the private steel industries mainly focuses on both sides of the success coin i.e., HRD and KMP. The main intention of these practices is to provide the best way for the better management of human and material resources as a whole. Generally, the KMP of private steel companies are doing positive role for knowledge development purposes.

\subsection{Jindal Steel \& Power Limited (JSPL)}

JSPL is a modern industrial powerhouse with a dominant presence in steel, power, mining, developing and manufacturing areas. Part of the US \$ 18 billion OP Jindal Group this youthful, dexterous and responsive organization is continually extending its capacities to fuel the fantasy venture that has seen it develop to a US $\$ 3.3$ billion business aggregate. The organization has submitted ventures surpassing the US $\$ 30$ billion later on and has a few business activities running all the while across landmasses. Driven by Mr Naveen Jindal, the most youthful child of the incredible legendary of Shri O.P. Jindal, the organization produces affordable and proficient steel and power through in reverse and forward integration.

However, from the widest flat products to an entire scope of long products, JSPL today sports a product portfolio that obliges markets across the steel value chain. The organization delivers the world's longest (121meter) rails and it is the first in the nation to make huge size equal spine radiates. JSPL works the biggest coalbased wipe iron plant on the planet and has an introduced limit of 3 MTPA (million tons for every annum) of steel at Raigarh in Chhattisgarh. Likewise, it has set up a 0.6 MTPA wire pole factory and a 1 MTPA limit bar plant at Patratu, Jharkhand, a medium and light underlying plant at Raigarh, Chhattisgarh and a 2.5 MTPA steel liquefying shop and a plate plant to create up to 5.00-meter-wide plates at Angul, Odisha.

An ambitious soul and the capacity to perceive future patterns have been the main thrust behind the organization's noteworthy development story. The organization is wedded to ideals \& beliefs like technological innovation, advancement procedure and mechanical authority and is supported by an exceptionally driven and dedicated labor-force of 15000 individuals. JSPL has been appraised as the second most noteworthy value creator in the world by the Boston Consulting Group, the eleventh quickest developing organization in India by Business World and has figured in the Forbes Asia list of Fab 50 companies. It has additionally been named among the Best Blue Chip companies and appraised as the Highest Wealth Creator by the Dalal Street Journal. Dun and Bradstreet have ranked fourth in the list of companies that generated the highest total income in the iron and steel segment. 


\subsubsection{Knowledge Management Practices of JSPL}

The KM practices of JSPL focusing on knowledge integration policies for making viable decisions for the concern. The knowledge development programs are also conducted by JSPL where each and every employee of the concern have the right to give his ideas, knowledge for the organization's development purpose. The JSPL plays a pivot role in KMP practices as it motivates the employees and encouraging them to the development of the organization's concern. Integration of knowledge practices are the key to success for this JSPL.

However, out of 416 reviews and ratings 5 of this plant, the highest rating falls under a good working environment i.e., 4.0. On the other hand, the second-highest activities of this plant i.e., both work-life balance and pay \& benefits activities have the same rating i.e., 3.7 and so on. This situation indicates that the $\mathrm{Km}$ practices of this plant efficiently functioning in terms of knowledge management practices.

\subsection{TATA Steel Limited}

Tata Steel Limited is an Indian global steel-production organization situated in Jamshedpur, Jharkhand, and is settled in Mumbai, Maharashtra, India. It is a subsidiary of the Tata Group. Previously known as Tata Iron and Steel Company Limited (TISCO), Tata Steel is among the top steel delivering organizations on the planet with a yearly unrefined steel limit of 34 million tons for each annum. It is one of the world's most geologically broadened steel makers, with activities and business presence across the world. The gathering (barring SEA activities) recorded a merged turnover of US\$19.7 billion in the monetary year finishing 31 March 2020 . It is the second biggest steel organization in India (estimated by homegrown creation) with a yearly limit of 13 million tons after SAIL.

Tata Steelworks in 26 nations with key tasks \& operations in India, Netherlands, and United Kingdom, and utilizes around 80,500 individuals. Its biggest plant (10 MTPA limit) is situated in Jamshedpur, Jharkhand. In 2007, Tata Steel gained the UK-based steel producer Corus. It was positioned 486th in the 2014 Fortune Global 500 positioning of the world's greatest organizations. It was the seventh most important Indian brand of 2013 as per Brand Finance.

\subsubsection{Knowledge Management Practices of TATA Steel}

In the year 1990s, Tata Steel started to present information on the board activities in the organization. It began with a little gathering of individuals from inside the organization. The gathering framed a "Knowledge Repository", where all the workers shared their encounters and information in one place. One year after the information storehouse was shaped, the organization framed "Knowledge communities", which was a stage for similar individuals to meet and share their experiences. In 2001, Tata Steel built up a "KM index" to assess the performance of individual representatives in the KM activity. Afterward, it connected execution assessment to KM and utilized a decent scorecard to screen the exhibition of individual workers, divisions, just as the organization in general, in KM.

All these activities of Tata Steel appear to have paid off; in mid-2003, Tata Steel was considered as one of Asia's Most Admired Knowledge Enterprises. It was the only steel organization on the planet to have gotten the MAKE award.

However, if we are considering the ratings and reviews of this plant then out of 257 reviews of the employees and rating 5, the highest ratings fall in both the activities i.e., skill development and job security activities i.e., 4.1. This statement indicates that the role of Tata steel companies in terms of KM practices is positive and widely spread in the whole of this plant.

\subsection{Bhusan Power and Steel Limited. (PSL)}

Bhushan Power and Steel was established in 1970, registered in 1999, and enlisted with the Registrar of Companies in Delhi. The organization set up its office in Chandigarh in 1973 to produce Tor steel and wire bar. It has 7 assembling offices in India. The organization is advanced by Sanjay Singal. Bhushan Power and Steel was obtained by JSW Steel in September 2019. JSW Steel's proposal of Rs. 19,700 crores were affirmed by NCLT. 
The Enforcement Directorate (ED) had connected assets worth Rs 4,025 crores of BPSL in October 2019 with respect to the continuous test. The National Company Law Appellate Tribunal (NCLAT) put a stay request, and the Ministry of Corporate Affairs expressed in the procedures that the ED didn't have the locale to connect resources in a bankruptcy interaction. The ED is looking for a legitimate assessment to take the argument under the steady gaze of the Supreme Court against the order of NCLAT.

\subsubsection{Knowledge Management Practices of Bhusan PSL}

The KMP practices of this plant are to motivate and encourage the employees so as to contribute their best ideas, knowledge, and practices for the development of the concern. This plant does a knowledge development program where all the superior and subordinate of the organization work together for the development of the organization. The KMP practices make the decision quicker in case of emergency situations.

The ratings and reviews of this plant out of 1157 reviews and 5 ratings, the highest ratings fall in both the activities i.e., skill development and job security i.e., 3.6. Moreover, in terms of career plan activities, this plant has 3.3 ratings out of 5 . The above statement indicates that the company has better management practices in terms of Knowledge management practices.

\section{Highlights of Knowledge Management Practices (KMP) in Private Steel Companies (PSC)}

The role of KMP in the case of Private Steel Companies (PSC) is also dynamic and widely acceptable. The employees of private steel companies are free to share and make decisions for the development purpose. For this, the employees are getting a reward. The decisions of the private steel companies are adopting a mutual decisionmaking process, where every staffs or employees have the right to share and contribute knowledge for achieving the target of the organizations. The KMP practices of private steel companies are specific and unique which manages both sides of the success coin i.e., HRD and KMP.

\section{Comparative Analysis of both Public and Private Steel Companies}

The role of public and private steel companies plays a dominating role in the economic development of the country. Due to the mixed economy practices, it, directly and indirectly, helps the nation for achieving a higher percentage of GDP. After the implementation of KMP in steel industries, the production remains to stand in an upward direction as it truly combining the important aspects i.e., both human and material resources for the organization to achieve its strategic goals and objectives.India is considered as one of the largest economy in the world due to its mixed economy and also coming under the second position in the world in steel production. The private and public steel industries have a special role in the development of the country by boosting the GDP with the help of the best HRD plan \& KM practice strategy. However, the following Table 4.7 represents the total crude steel production from 2014 to $2020 \mathrm{~F}$.Y.

Table 9.1. Indian Crude Steel Production (in Million Tons)

\begin{tabular}{|l|c|c|c|c|c|c|}
\hline \multicolumn{1}{|c|}{ Sector } & $\mathbf{2 0 1 4 - 1 5}$ & $\mathbf{2 0 1 5 - 1 6}$ & $\mathbf{2 0 1 6 - 1 7}$ & $\mathbf{2 0 1 7 - 1 8}$ & $\mathbf{2 0 1 8 - 1 9}$ & $\mathbf{( 2 0 1 9 - 2 0 )} *$ \\
\hline Public Sector & 17.21 & 17.92 & 18.46 & 19.75 & 21.49 & 15.34 \\
\hline Private sector & 71.77 & 71.87 & 79.48 & 83.38 & 89.43 & 66.85 \\
\hline Total Production & 88.98 & 89.79 & 97.94 & 103.13 & 110.92 & 82.19 \\
\hline $\begin{array}{l}\text { Share of Public } \\
\text { Sector }\end{array}$ & 19 & 20 & 19 & 19 & 19 & 19 \\
\hline
\end{tabular}

The above Table No. 4.7 shows the total production of steel in India. This table shows that the production of steel in the case of the Public sector gradually increases from 2014-15 F.Y to 2019-20 F.Y. The private steel industries have more production as compared to public sector steel industries due to more shares. The production of the private industries is also in increasing stage throughout the year.

\section{Conclusion of the study}

From the above elaboration of this chapter, it is concluded that the performance of both public and private steel industries in terms of HRD and KM practices quite similar to each other. After the implementation of KM practices in the steel industries the production as well performance growth in the organization are in an upward 
direction. These two aspects i.e., HRD and KMP have a great impact on production growth as well as the financial performance of the organization. The KM practices promote the efficiency of the employees and motivate them to do his/her duty well. The KMP process helps the personnel to develop their skill, knowledge, and experience in the organization. These practice energies the employees to participate in the strategic decisionmaking process. This process generally helps the organization to take decisions faster in case of emergencies. Hence, the overall developments of both public and private companies have a significant role in HRD and KMP practices. These two important aspects not only help the organization the development of the economy but also helps to maintain a positive impact on the performance level of each and every employee of the organization.

Table 10.1. Comparative Study on Both Public \& Private Steel Industries on KMP

\begin{tabular}{|c|c|c|c|}
\hline Sl. No. & Public Steel Companies & $\begin{array}{ll}\text { Private } & \text { Steel } \\
\text { Companies } & \\
\end{array}$ & Universal Findings \\
\hline 1 & Knowledge Sharing Tools & $\begin{array}{c}\text { Knowledge } \\
\text { Repository System }\end{array}$ & $\begin{array}{l}\text { Both of these tools are indicated, sharing } \\
\text { of employees idea for achieving the } \\
\text { goals. }\end{array}$ \\
\hline 2 & Knowledge Sharing policy & Knowledge System & $\begin{array}{l}\text { The policies are stated in terms of } \\
\text { system for discrimination of knowledge } \\
\text { in the organization. }\end{array}$ \\
\hline 3 & $\begin{array}{l}\text { Rewarding for Motivation of } \\
\text { the Employees }\end{array}$ & $\begin{array}{c}\text { Rewarding for } \\
\text { Innovation of the } \\
\text { employees }\end{array}$ & $\begin{array}{l}\text { Both these techniques are meant for } \\
\text { knowledge sharing }\end{array}$ \\
\hline 4 & Integration of Knowledge & Mutual decisions & $\begin{array}{l}\text { Both of these tactics are meant for the } \\
\text { participation in decision making }\end{array}$ \\
\hline 5 & Knowledge measurement & $\begin{array}{l}\text { Knowledge } \\
\text { Management Index } \\
\text { (KMI) }\end{array}$ & $\begin{array}{l}\text { Both these tools used for knowledge } \\
\text { analysis and measurement so as to } \\
\text { choose the best idea from different } \\
\text { alternatives }\end{array}$ \\
\hline 6 & Knowledge Culture & $\begin{array}{l}\text { Knowledge } \\
\text { Environment }\end{array}$ & $\begin{array}{l}\text { The mentioned two aspects developing } \\
\text { such kind of climate or environment } \\
\text { where each and every personnel have a } \\
\text { chance to contribute and participate in } \\
\text { the strategic management decision- } \\
\text { making process, }\end{array}$ \\
\hline
\end{tabular}

Moreover, the performance of the Steel Authority of India Limited (SAIL) has a positive impact on the economy. These industries are promoting and motivating the employees for achieving the organizational strategic goals. On the other hand, the private steel industries such as TATA Steel, JSPL, etc. also have a great contribution to the economic development of the country. There is a positive correlation between productivity growth and performance growth in the steel industries of India.

\section{Acknowledgment}

The Corresponding author is highly obliged to Prof. Sudhansu Sekhar Rath, Former Vice Chancellor G.M. University, Sambalpur, India for his support and encouragement. This research is part of my Post. Doc. thesis to be submitted Sambalpur University, Odisha.

\section{References}

1. Ministry of Steel, GOI, Annual Report-2019-20

2. Mohanty, M., Mishra, P. (2008). HR interventions in turnaround strategy: A study of Rourkela Steel Plant. Management and Labour Studies. 33 (4). 525-546.

3. Nonaka, I., Takeuchi, H. (1995). The Knowledge-Creating Company. Oxford University Press

4. Nonaka, I., Umemoto, K. and Senoo, D. (1996). From information processing to knowledge creation: a paradigm shift in business management. Technology in Society, 18(2), 203-218.

5. Rao, T V (1999). HRD Audit, New Delhi: Response Books (A Division of Sage

6. Rao, T. V. and Abraham, E. (1986). Human Resource Development Climate in Indian organisation, in Rao T.V. \& Pereira D.F. (Eds.), Recent Experiences in Human Resources Development, New Delhi, Oxford \& IBH : 70-98. 
7. Rao, T. V., and Abraham, E. (1986).HRD climate in organizations. In T. V. Rao (Eds),Readings in Human Resource development, Oxford \& IBH publishing Co. Pvt. Ltd, New Delhi, 36-45.

8. Rao, T.V., and Abraham, E. (1990). The HRD Climate Survey. In J. W. Pfeiffer (Ed.), the 1990 Annual: Developing Human Resources, University Associates, San Diego, CA.

9. Steel authority of India limited Rourkela Steel plant, Annual Business Plan: 2020-21

10. Steel Authority of India limited, Annual Report- 2019-20

11. Swanson R. A. and Holton III, E. F. (2009). Foundations of human resource development (2 ed).San Francisco, CA: Berrett-Koehler Publishers, Inc.

12. Swanson R. A. and Holton III, E. F. (2009). Foundations of human resource development (2 ed).San Francisco, CA: Berrett-Koehler Publishers, Inc.

13. Swanson, R. A. (2001). Human resource development and its underlying theory, Human Resource Development International, 4(3), 299-312

14. Swanson, R. A. and Holton, E. F. (2001). Foundations of Human Resource Development, San Francisco: Berrett-Koehler.

15. Swanson, R. A., and Holton, E. F. (1997). Human Resource Development Handbook: Linking Research and Practice. San Francisco: BerrettKoehler.

16. The Indian Steel Industry: Growth, Challenges and Digital Disruption, Indian Steel Associations Report, Nov-2019

17. University Press, New York.

18. Weinberger, L. A. (1998). Commonly held theories of human resource development. Human Resource Development International, 1(1), 75-93.

19. Wernerfelt, B. (1984) 'The Resource Based View of the Firm', Strategic Management Journal 5.2: 171-80.

\section{Websites}

20. www.sail.co.in

21. https://www.jindalsteelpower.com/businesses/angul.html

22. http://tatasteelbsl.co.in/home.html

23. https://www.tatasteel.com/media/newsroom/press-releases/india/2018/tata-steel-begins-5-MTPAphase-ii-expansion-of-its-kalinganagar-plant/

24. https://www.bhushanpowersteel.com/profile.html

25. https://www.jindalsteelpower.com/businesses/raigarh.html

26. https://www.aionjsw.in/

27. https://www.tatasteel.com

28. https://www.jindalsteelpower.com/careers/training.html

29. https://www.tatasteel.com/sustainability-old/sustainability-pillars/hr-practices/\#

30. http://mahamayagroup.in/Media/Default/PDF/CODE\%20OF\%20CONDUCT.pdf

31. https://www.bhushanpowersteel.com/hr-philosophy.html

32. https://www.jsw.in/sites/default/files/assets/industry/steel/IR/CSR/Sustainability\%20Policies/Polic y\%20on\%20\%20Employee\%20Welfare\%20-\%20III.pdfhttps://www.tatasteel.com/sustainabilityold/sustainability-pillars/hr-practices/\#

33. http://mahamayagroup.in/Media/Default/PDF/CODE\%20OF\%20CONDUCT.pdf

34. https://www.bhushanpowersteel.com/hr-philosophy.html

35. https://www.jsw.in/sites/default/files/assets/industry/steel/IR/CSR/Sustainability\%20Policies/Polic y\%20on\%20\%20Employee\%20Welfare\%20-\%20III.pdf

36. This is Google's cache of https://www.glassdoor.co.in/Reviews/Steel-Authority-of-India-ReviewsE7843.htm. It is a snapshot of the page as it appeared on 15 Mar 2021 03:13:47 GMT. The current page could have changed in the meantime. Learn more.

37. This is Google's cache of https://www.glassdoor.co.in/Reviews/SAIL-Reviews-E1020363.htm. It is a snapshot of the page as it appeared on 4 Mar 2021 09:56:33 GMT. The current page could have changed in the meantime. Learn more.

38. SAIL, Annual Report 13-14

39. SAIL, Annual Report 19-20

40. SAIL, Financial Year Book 10-20 